\title{
Analisis Dampak Kebijakan Pemerintah Terhadap Daya Saing Komoditas Kelapa di Kabupaten Flores Timur
}

\author{
Krisna Setiawan* \\ Haryati M. Sengadji* \\ Program Studi Manajemen Agribisnis, Politeknik Pertanian Negeri Kupang \\ Email:eiwhan8@gmail.com
}

\begin{abstract}
Abstrak
Penelitian ini bertujuan menganalisis divergensi dan dampak kebijakan (distorsi pasar) pada input dan output dari komoditas kelapa di Kabupaten Flores Timur. Metode analisis data penelitian menggunakan Policy Analysis Matrix (PAM). Hasil penelitian menunjukkan (1) Dampak dari instrumen kebijakan pemerintah dalam subsidi input saat ini memberikan perlindungan terhadap input domestik. Kondisi ini mengakibatkan petani di Kabupaten Flores Timur sebagai produsen kelapa tidak dapat memperoleh input domestik lebih murah daripada harga sosialnya (biaya domestik tinggi), sementara keuntungan diperoleh produsen input domestik. (2) Dampak dari instrumen kebijakan pemerintah dalam harga dan mekanisme pasar output kelapa saat ini telah memberi perlindungan terhadap pembentukan harga kelapa, sehingga pendapatan yang diterima petani lebih tinggi daripada harga sosial yang seharusnya. (3) Dampak dari instrumen kebijakan pemerintah dan mekanisme pasar input- output yang berlaku saat ini kurang memberi rangsangan (disinsentif) terhadap petani produsen kelapa di Kabupaten Flores Timur, sehingga nilai tambah atau keuntungan yang diperoleh petani lebih rendah daripada keuntungan sosial yang seharusnya diterima petani.
\end{abstract}

\section{Kata kunci: Kelapa; kebijakan; PAM}

\begin{abstract}
This study aimed to analyze the divergence and the impact of policies (market distortion) at the input and output of coconut in East Flores. Methods of data analysis using the Policy Analysis Matrix (PAM). The results showed (1) The impact of government policy instruments in input subsidies currently providing protection against domestic input. These conditions resulted in farmers in East Flores district as a coconut producer can not obtain domestic inputs cheaper than the social price (high domestic costs), while profits for producers of domestic inputs. (2) The impact of government policy instruments and mechanisms in the price of coconut output current market has provided protection against the formation of coconut prices, so that the income received by farmers is higher than the social price should be. (3) The impact of government policy instruments and market mechanisms input-output current giving less stimulation (disincentives) to the coconut producing farmers in East Flores district, so that the added value or benefits of farmers is lower than it would have received social benefits farmers.
\end{abstract}

Keywords: Coconut; policy; PAM 


\section{PENDAHULUAN}

Pemerintah di setiap negara pada umumnya memiliki andil yang cukup besar dalam melakukan intervensi baik dalam hal produksi maupun perdagangan komoditas pertanian. Untuk dapat menambah devisa negara dan meningkatkan pendapatan daerah serta meningkatkan kesejahteraan petani, maka pemerintah Kabupaten Flores Timur diberikan kewenangan dan tanggung jawab untuk mengatur dan mengelola sumberdaya nasional yang tersedia di wilayah daerah bersangkutan.

Salah satu komoditas perkebunan di Kabupaten Flores Timur yang memiliki potensi untuk dikembangkan adalah tanaman kelapa. Oleh karena itu sebaiknya pengembangan suatu komoditas perkebunan dikonsentrasikan pada daerah-daerah atau wilayah yang memiliki keunggulan komparatif dan kompetitif. Komoditas yang memiliki daya saing dan mampu mengenali pasarnya akan terpilih oleh konsumen. Daya saing sangat identik dengan kualitas sedangkan harga merupakan indikator utama dari kualitas. Oleh karena itu, komoditas yang berkualitas tinggi akan dinilai dengan harga yang tinggi dan begitu juga sebaliknya. Dengan demikian diharapkan komoditas kelapa di Kabupaten Flores Timur memiliki daya saing serta mampu menambah pendapatan daerah.

Mengingat kelapa merupakan komoditas perkebunan yang berorientasi ekspor, perdagangannya tidak terlepas dari kebijakan pemerintah seperti tarif, kuota, subsidi, dan pajak. Kebijakan tersebut erat kaitannya dengan output dan input pengusahaan komoditas kelapa. Kebijakan yang mengakibatkan biaya input menurun dan menambah nilai guna output akan meningkatkan daya saing komoditas kelapa, sedangkan kebijakan yang mengakibatkan biaya input menjadi naik dan nilai guna output menurun akan menurunkan juga daya saing. Oleh karena itu, maka diperlukan analisis kebijakan pemerintah terhadap komponen input maupun output yang mempengaruhi daya saing pengusahaan komoditas kelapa di Kabupaten Flores Timur

Penelitian ini bertujuan untuk menganalisis divergensi dan dampak kebijakan (distorsi pasar) pada input dan output dari komoditas kelapa. Dari penelitian ini diharapkan dapat diambil kebijakan yang tepat untuk meningkatkan daya saing kelapa lokal di Kabupaten Flores Timur.

\section{METODE PENELITIAN}

Penelitian ini dilaksanakan pada bulan Maret hingga Oktober 2016 di Kabupaten Flores Timur yaitu pada Kecamatan Wulanggitang dan Kecamatan Adonara Timur. Pemilihan lokasi secara sengaja (purposive) dengan pertimbangan merupakan daerah yang memiliki luas areal tanam lebih dari 1000 Ha dan produksi kelapa lebih dari 750 ton. Sampel petani diambil secara Simple Random Sampling dimana setiap populasi yang ada mempunyai kesempatan yang sama untuk dijadikan sampel. Jumlah sampel yang diambil adalah sebanyak 100 responden.

Penelitian analisis dampak kebijakan pemerintah terhadap daya saing komoditas kelapa menggunakan metode Policy Analysis Matrix (PAM) yang dikembangkan oleh Monke dan Pearson 
(1995). Adapun tahapan dalam penyusunan Tabel PAM adalah sebagai berikut:

1. Mengidentifikasi seluruh input yang digunakan dalam proses produksi.
2. Mengalokasikan input tradable dan input non tradable.

3. Menghitung harga bayangan input, output, dan nilai tukar uang

4. Menganalisis daya saing dan dampak kebijakan dengan model PAM.

Tabel 1. Matriks Analisis Kebijakan (Policy Analysis Matrix)

\begin{tabular}{lcccc}
\hline & & \multicolumn{2}{c}{ Biaya } & \\
\cline { 3 - 4 } & Penerimaan & $\begin{array}{c}\text { Input } \\
\text { Tradable }\end{array}$ & $\begin{array}{c}\text { Input } \\
\text { Non Tradable }\end{array}$ & Keuntungan \\
\hline Harga Privat & $\mathrm{A}$ & $\mathrm{B}$ & $\mathrm{C}$ & $\mathrm{D}$ \\
Harga Sosial & $\mathrm{E}$ & $\mathrm{F}$ & $\mathrm{G}$ & $\mathrm{H}$ \\
Dampak Kebijakan & $\mathrm{I}$ & $\mathrm{J}$ & $\mathrm{K}$ & $\mathrm{L}$ \\
\hline
\end{tabular}

Sumber: Monke and Pearson, (1995) dan Pearson dkk, (2005)

Keterangan :

Keuntungan Privat $(D)=(A)-(B+C)$

Keuntungan Sosial $(H)=(E)-(F+G)$

Transfer Output $(\mathrm{I})=(\mathrm{A})-(\mathrm{E})$

Transfer Input $(\mathrm{J})=(\mathrm{B})-(\mathrm{F})$

Transfer Faktor $(\mathrm{K})=(\mathrm{C})-(\mathrm{G})$

Transfer Bersih (L) $=(\mathrm{D})-(\mathrm{H})=\mathrm{I}-(\mathrm{J}+\mathrm{K})$

Rasio Biaya Privat $(\mathrm{PCR})=\mathrm{C} /(\mathrm{A}-\mathrm{B})$

Rasio Biaya Sumberdaya

Domestik(DRCR) $=$ G $/($ E-F $)$

Koefisien Proteksi Output Nominal

$(\mathrm{NPCO})=\mathrm{A} / \mathrm{E}$

Koefisien Proteksi Input Nominal (NPCI)

$=\mathrm{B} / \mathrm{F}$

Koefisien Proteksi Efektif $(\mathrm{EPC})=(\mathrm{A}-\mathrm{B}) /$ (E-F)

Koefisien Keuntungan (PC) $=\mathrm{D} / \mathrm{H}$

Rasio Subsidi Bagi Produsen (SRP) = L/E

\section{Analisis Dampak Kebijakan \\ Pemerintah}

Dampak kebijakan pemerintah yang diidentifikasikan dari analisis PAM meliputi dampak kebijakan pemerintah terhadap output, input dan dampak kebijakan terhadap input-output.

\section{Dampak Kebijakan Output}

Kebijakan pemerintah terhadap output dijelaskan oleh nilai Transfer Output (Ouput Transfer atau OT) dan Koefisien Proteksi Output Nominal
(Nominal Protection Coefficient Output atau NPCO).

Nilai OT merupakan selisih antara penerimaan yang dihitung atas harga privat dengan penerimaan yang dihitung berdasarkan harga sosial. Nilai OT yang positif (OT > 1) berarti masyarakat atau konsumen harus membeli dengan harga yang lebih tinggi dari harga yang seharusnya dibayarkan, dan produsen menerima harga yang lebih tinggi dari harga yang seharusnya diterima sehingga masyarakat dirugikan. Sebaliknya, apabila nilai OT kurang dari satu atau negatif (OT < 1) maka yang terjadi adalah masyarakat menerima insentif dari produsen dan produsen yang dirugikan. OT dapat dirumuskan sebagai berikut:

$$
\begin{aligned}
\begin{array}{l}
\text { Output } \\
\text { Transfer }
\end{array} & \mathbf{A}-\mathbf{E} \\
& =\begin{array}{l}
\text { Penerimaan Privat }- \\
\text { Penerimaan Sosial }
\end{array}
\end{aligned}
$$

NPCO merupakan rasio antara penerimaan yang dihitung berdasarkan harga privat dengan penerimaan yang dihitung berdasarkan harga sosial. NPCO digunakan untuk mengukur dampak insentif kebijakan pemerintah yang 
menyebabkan terjadinya perbedaan nilai output yang diukur dengan harga privat dan sosial. Jika nilai NPCO lebih kecil dari satu $($ NPCO < 1) berarti menunjukkan adanya kebijakan pemerintah yang menghambat ekspor output yang berupa subsidi negatif (pajak) dan berakibat terjadinya pengurangan penerimaan produsen. Sementara apabila nilai NPCO lebih besar dari satu (NPCO > 1) maka yang terjadi adalah sebaliknya yaitu produsen menerima subsidi atas output dari pemerintah karena pemerintah menaikkan harga output di pasar domestik di atas harga dunia (harga efisiennya). NPCO dapat dirumuskan sebagai berikut:

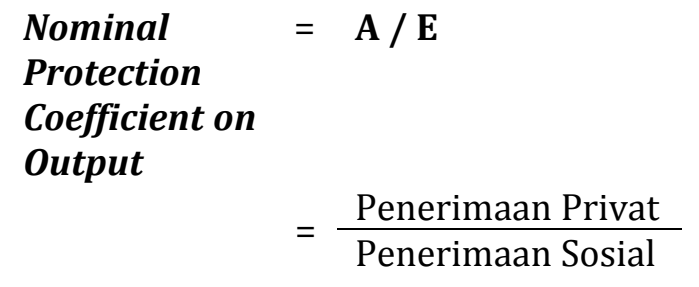

$$
=\frac{\text { Penerimaan Privat }}{\text { Penerimaan Sosial }}
$$

\section{Dampak Kebijakan Input}

Dampak kebijakan pemerintah terhadap input tradable dijelaskan dengan Transfer Input (Input Transfer atau IT) dan Koefisien Proteksi Input Nominal (Nominal Protection Coefficient Input atau NPCI), sedangkan dampak kebijakan input domestik dijelaskan oleh Transfer Faktor (Factor Transfer atau FT).

$$
\text { Nilai Input Transfer }
$$

menunjukkan kebijakan pemerintah yang diterapkan pada input tradable yang mengakibatkan terjadinya perbedaan input tradable privat dan sosial. Nilai IT positif menunjukkan kebijakan pemerintah pada input tradable menyebabkan keuntungan yang diterima secara privat lebih besar dibandingkan tanpa adanya kebijakan. Nilai IT negatif menunjukkan kebijakan pemerintah menyebabkan keuntungan yang diterima secara finansial lebih kecil dibandingkan tanpa adanya kebijakan. IT dapat dirumuskan :

$$
\begin{aligned}
& \text { Input }= \\
& \text { Transfer }-\mathbf{F} \\
&= \text { Biaya Input Tradable } \\
& \text { Privat }- \text { Biaya Input } \\
& \text { Tradable Sosial }
\end{aligned}
$$

NPCI adalah rasio antara biaya input tradable berdasarkan harga privat dan biaya input tradable berdasarkan harga sosial. Perbedaan antara kedua biaya tersebut menunjukkan adanya kebijakan yang mengakibatkan harga privat input tradable berbeda dengan harga sosial input tradable. Nilai NPCI lebih dari satu (NPCI > 1) menunjukkan adanya proteksi terhadap produsen input, sementara sektor yang menggunakan input tersebut akan dirugikan dengan tingginya biaya produksi. Nilai NPCI lebih kecil dari satu $(\mathrm{NPCI}<1)$ menunjukan adanya hambatan ekspor input, sehingga produksi menggunakan input lokal. NPCI dapat dirumuskan sebagai berikut:

\begin{tabular}{ll}
$\begin{array}{l}\text { Nominal Protection } \\
\text { Coefficient on Input }\end{array}$ & $\mathbf{B} / \mathbf{F}$ \\
& Biaya Input \\
$=$ & Tradable \\
& Privat \\
\hline & Biaya Input \\
& Tradable \\
& Sosial
\end{tabular}

Nilai Factor Transfer menunjukkan pegaruh kebijakan pemerintah terhadap input domestik. Nilai FT menunjukkan besarnya subsidi terhadap input non tradable. Jika nilai FT bernilai positif berarti terdapat subsidi negatif pada input non tradable, sedangkan nilai FT negatif berarti terdapat subsidi positif pada input non 
tradable. FT dapat dirumuskan sebagai berikut:

$$
\begin{array}{ll}
\begin{array}{l}
\text { Factor } \\
\text { Transfer }=
\end{array} & \mathbf{C}-\mathbf{G} \\
= & \text { Biaya Input Non } \\
& \text { Tradable Privat - Biaya } \\
& \text { Input Non Tradable } \\
& \text { Sosial }
\end{array}
$$

\section{Dampak Kebijakan Input-Output}

Pengaruh kebijakan input-output dapat dijelaskan melalui analisis Koefisien Proteksi Efektif (Effective Protection Coefficient atau EPC), Transfer Bersih (Net Transfer atau NT), Koefisien Keuntungan (Profitability Coefficient atau PC) dan Rasio Subsidi bagi Produsen (Subsidy Ratio to Producers atau SRP).

Koefisien Proteksi Efektif (EPC) adalah analisis gabungan proteksi output dengan proteksi input. Nilai EPC menggambarkan sejauh mana kebijakan pemerintah bersifat melindungi atau menghambat produksi domestik secara efektif. Nilai EPC lebih besar dari satu (EPC > 1) menunjukkan kebijakan untuk melindungi produsen domestik berjalan dengan efektif. Jika nilai EPC lebih kecil dari satu $(E P C<1)$ maka kebijakan untuk melindungi produsen domestik tidak berjalan dengan efektif. EPC dapat dirumuskan sebagai berikut:

\section{Effective $=(\mathrm{A}-\mathrm{B}) /(\mathrm{E}-\mathrm{F})$ \\ Protection \\ Coefficient}

\begin{tabular}{l} 
Penerimaan Privat - \\
Biaya Input Tradable \\
Privat \\
\hline Penerimaan Sosial - \\
Biaya Input Tradable \\
Sosial
\end{tabular}

Transfer Bersih (Net Transfer atau NT) adalah selisih antara keuntungan privat dengan keuntungan sosial. Nilai NT juga menggambarkan selisih antara transfer output dengan transfer input. Jika nilai NT lebih besar dari nol (NT $>0$ ), maka nilai tersebut menunjukkan tambahan surplus produsen yang disebabkan oleh kebijakan pemerintah yang dilakukan pada input dan output. Jika nilai NT lebih kecil dari nol $(\mathrm{NT}<0)$ maka yang terjadi adalah sebaliknya. NT dapat dirumuskan sebagai berikut:

$$
\begin{array}{ll}
\text { Net } & =\mathbf{D}-\mathbf{H} \\
\text { Transfer } & = \\
& \text { Keuntungan Privat }- \\
& \text { Keuntungan Sosial }
\end{array}
$$

Koefisien

Keuntungan

(Profitability Coefficient atau PC) adalah perbandingan antara keuntungan bersih privat dengan keuntungan bersih sosial. Nilai PC yang kurang dari satu $(\mathrm{PC}<1)$ menunjukkan kebijakan pemerintah membuat keuntungan yang diterima produsen lebih kecil bila dibandingkan tanpa ada kebijakan. Jika nilai PC lebih dari satu (PC > 1) maka yang terjadi adalah sebaliknya. PC dapat dirumuskan sebagai berikut:

$$
\begin{array}{ll}
\begin{array}{l}
\text { Profitability } \\
\text { Coefficient }
\end{array} & \mathbf{D} / \mathbf{H} \\
& =\frac{\text { Keuntungan Privat }}{\text { Keuntungan Sosial }}
\end{array}
$$

Rasio Subsidi bagi Produsen (Subsidi Ratio to Producers atau SRP) menunjukkan insentif bersih atas penerimaan yang dihitung dengan harga sosial. Nilai SRP negatif menunjukkan kebijakan pemerintah yang berlaku membuat produsen mengeluarkan biaya produksi lebih besar dari biaya imbangan untuk berproduksi. Jika nilai SRP adalah positif maka yang terjadi adalah sebaliknya. SRP dapat dirumuskan sebagai berikut: 


\section{Subsidy $=\mathrm{L} / \mathrm{E}$ \\ Ratio to \\ Producers}

$$
=\frac{\text { Transfer Bersih }}{\text { Penerimaan Sosial }}
$$

\section{HASIL DAN PEMBAHASAN}

Gambaran Usahatani Kelapa di Kabupaten

Flores Timur

Luas lahan garapan tanaman kelapa di Kabupaten Flores Timur ratarata sebesar 1,3 ha, dengan tidak memperhatikan jarak tanam. Dengan demikian jumlah pohon kelapa untuk satu luasan yang sama akan berbeda-beda. Namun bila dirata-ratakan jumlah kepadatan tanaman kelapa per hektarnya adalah sebanyak 156 pohon.

Umur rata-rata tanaman kelapa di Kabupaten Flores Timur adalah diatas 40 tahun sehingga produktivitasnya mulai menurun. Harapan kedepan adalah dengan melakukan peremajaan kembali tanaman kelapa. Jenis varietas kelapa yang diusahakan adalah varietas lokal atau kelapa dalam. Rata-rata produksi buah kelapa per hektar adalah sebesar $10.714 \mathrm{~kg} /$ tahun. Buah kelapa tua yang dipanen, selain untuk dijual utuh juga diolah petani untuk dijadikan minyak kelapa dan kopra. Pada saat musim hujan petani lebih banyak mengolah kelapa menjadi minyak kelapa dan saat musim kemarau kelapa lebih banyak diolah menjadi kopra. Selama ini produk kelapa olahan masih terbatas. Padahal jika dikelola dengan baik hampir seluruh bagian dari tanaman kelapa mempunyai potensi nilai ekonomi.

Rata-rata luas lahan garapan, umur tanaman, kepadatan tanaman dan produksi kelapa disajikan pada tabel 2 berikut ini.
Tabel 2. Rata-Rata Luas Lahan, Umur, Populasi, dan Produksi Kelapa di Kabupaten Flores Timur Tahun 2016

\begin{tabular}{clc}
\hline No & \multicolumn{1}{c}{ Uraian } & Jumlah \\
\hline 1 & $\begin{array}{l}\text { Rata-rata luas lahan } \\
\text { garapan (ha) }\end{array}$ & 1,3 \\
& $\begin{array}{l}\text { Rata-rata kepadatan } \\
\text { tanaman kelapa } \\
\text { (pohon/ha) }\end{array}$ \\
3 & $\begin{array}{l}\text { Rata-rata umur } \\
\text { tanaman kelapa } \\
\text { (tahun) }\end{array}$ \\
4 & $\begin{array}{l}\text { Rata-rata produksi } \\
\text { (kg/tahun) }\end{array}$ & 156 \\
\hline
\end{tabular}

Sumber: Analisis Data Primer, 2016

\section{Asumsi Ekonomi Makro}

Asumsi makro ekonomi yang digunakan pada analisis Policy Analysis Matrix (PAM) adalah tingkat suku bunga nominal (\% per tahun), yang diperoleh dari informasi tingkat bunga kredit formal (bank persero, bank pemerintah daerah, bank swasta nasional, bank asing dan bank campuran, bank umum, dan lembaga kredit lainnya). Tingkat suku bunga nominal yang digunakan adalah rata-rata tingkat bunga privat untuk modal yang bersumber dari lembaga kredit formal yang ada di lokasi penelitian, yakni sebesar 10,61\% per tahun

Untuk tingkat suku bunga sosial (\% per tahun), diperoleh dari penjumlahan social opportunity cost of capital yang diasumsikan sebesar 15\% per tahun ditambah dengan laju inflasi nasional pada tahun penelitian. Hal ini sesuai dengan pengalaman historis negara-negara di Asia Tenggara ketika berada pada tahap pembangunan yang sama dengan Indonesia saat ini. Laju inflasi nasional Tahun 2016 yakni sebesar 4\% dengan demikian tingkat suku bunga sosial berada pada besaran 
19\% (Pearson, dkk, 2005 dan Bank Indonesia, 2016). Nilai tukar yang digunakan dalam penelitian ini sebesar Rp 13.249,00 per US Dollar (Bank Indonesia, 2016).

\section{Policy Analysis Matrix (PAM) Multi Periode} Usahatani Kelapa

PAM multi-periode adalah PAM yang digunakan untuk komoditas yang masa tanam dan panennya (siklus produksi) berlangsung dalam waktu yang panjang. Perhitungan PAM untuk komoditas dengan rentang waktu yang panjang seperti itu memerlukan tabel PAM untuk setiap periode, kemudian menghitung net present value (NPV) seluruh periode tersebut. Proses diskonto (discounting) diperlukan dalam kasus ini karena nilai penerimaan (revenue, $\mathrm{R}$ ) dan biaya (cost, C) yang akan diterima/dikeluarkan di masa yang akan datang akan lebih kecil nilainya bila dinilai pada saat ini (Pearson, dkk, 2005).

Daya saing usahatani kelapa dapat diketahui dengan menggunakan Policy Analysis Matrix (PAM). Berikut hasil dari analisis PAM seperti yang disajikan pada tabel 3.

Tabel 3. PAM usahatani kelapa di Kabupaten Flores Timur, 2016

\begin{tabular}{|c|c|c|c|c|}
\hline \multirow{2}{*}{ Uraian } & \multirow{2}{*}{ Penerimaan } & \multicolumn{2}{|c|}{ Biaya } & \multirow{2}{*}{ Keuntungan } \\
\hline & & Tradable & Domestik & \\
\hline Harga Privat & 53.384 .585 & 0 & 33.828 .787 & 19.555 .798 \\
\hline Harga Sosial & 43.182 .476 & 0 & 16.112 .861 & 27.069 .615 \\
\hline Dampak Kebijakan & 10.202 .109 & 0 & 17.715 .926 & -7.513 .817 \\
\hline
\end{tabular}

Sumber: Analisis data primer, 2016

\section{Analisis Dampak Kebijakan Pemerintah pada Input}

Kebijakan pemerintah terhadap input produksi dapat dilihat dari nilai Transfer Input (IT), Transfer Faktor (FT), dan Koefisien Proteksi Nominal pada Input (Nominal Protection Coefficient on Inputs/ NPCI). Penerapan kebijakan ini tidak terlepas dari upaya pemerintah untuk melindungi produsen. Informasi selengkapnya mengenai nilai IT, TF dan NPCI dapat dilihat pada tabel 4 berikut.
Tabel 4. Nilai Parameter Dampak Kebijakan pada Bidang Input Komoditas Kelapa di Kabupaten Flores Timur, 2016

\begin{tabular}{lc}
\hline Parameter & Nilai \\
\hline Input Transfer (IT) & 0 \\
Factor Transfer (FT) & 17.715 .926 \\
Nominal Protection & 0 \\
Coefficient Inputs (NPCI) & \\
\hline
\end{tabular}

Sumber: Analisis Data primer, 2016

Namun dikarenakan pada usahatani kelapa di Kabupaten Flores Timur yang diusahakan ini tidak menggunakan pupuk dan obat-obatan dalam kegiatan pemeliharaan tanaman kelapa, maka Input Transfer (IT) dan (Nominal Protection Coefficient on Inputs/ NPCI) tidak ada nilainya.

$$
\text { Factor Transfer (FT) adalah }
$$


perbedaan harga sosial dengan harga privat yang diterima oleh petani kelapa untuk pembayaran faktor produksi domestik Hasil analisis menunjukkan bahwa nilai Factor Transfer pada penelitian ini adalah positif yaitu 17.715.926 yang menunjukkan bahwa harga input domestik yang dikeluarkan pada tingkat harga privat lebih tinggi dibandingkan dengan biaya domestik yang dikeluarkan pada tingkat harga ekonomi. Artinya, adanya kebijakan pemerintah yang bersifat melindungi input domestik. Kondisi ini mengakibatkan petani kelapa di Kabupaten Flores Timur sebagai produsen kelapa tidak dapat memperoleh input domestik lebih murah daripada harga sosialnya, sementara produsen input domestik memperoleh keuntungan sebesar Rp 17.715.926.

\section{Analisis Dampak Kebijakan Pemerintah} pada Output

Kebijakan pemerintah dalam output dapat dilihat dari dua indikator yaitu transfer output (Output Transfer/ OT) dan koefisien proteksi output nominal (Nominal Protection Coefficient Outputs/ NPCO). Informasi selengkapnya mengenai nilai OT dan NPCO dapat dilihat pada tabel 5 berikut ini.

Tabel 5. Nilai Parameter Dampak Kebijakan pada Bidang Output Komoditas Kelapa di Kabupaten Flores Timur, 2016

\begin{tabular}{lrc}
\hline Parameter & Nilai \\
\hline $\begin{array}{l}\text { Output } \\
\text { (OT) }\end{array}$ & Transfer & 10.202 .109 \\
$\begin{array}{l}\text { Nominal } \\
\text { Coefficient }\end{array}$ & Outputs & 1,24 \\
(NPCO) & & \\
\hline
\end{tabular}

Sumber: Analisis Data primer, 2016
Nilai Output Transfer (OT) merupakan selisih antara penerimaan yang dihitung atas harga privat dengan penerimaan yang dihitung berdasarkan harga sosial. Nilai Transfer Output yang dihasilkan pada pengusahaan komoditas kelapa di Kabupaten Flores Timur adalah positif yaitu 10.202.109. Hal ini berarti masyarakat atau konsumen membeli dengan harga yang lebih tinggi dari harga yang seharusnya dibayarkan kepada produsen sehingga petani diuntungkan. Dengan kata lain, penerimaan yang diterima petani kelapa lebih besar $\mathrm{Rp}$ 10.202.109 daripada penerimaan sesungguhnya tanpa kebijakan pemerintah.

Nilai Nominal Protection Coefficient Outputs (NPCO) adalah rasio antara penerimaan berdasarkan harga privat dengan penerimaan berdasarkan harga sosial. Penerimaan privat pada penelitian ini adalah $\mathrm{Rp}$ 53.384.585 sedangkan penerimaan sosial $\mathrm{Rp}$ 43.182.476 sehingga nilai NPCO yang dihasilkan lebih besar dari satu, yaitu sebesar 1,24. Nilai NPCO yang lebih besar dari satu menunjukkan bahwa harga domestik lebih tinggi dari harga internasional/dunia.

Analisis Dampak Kebijakan Pemerintah pada Input-Output

Untuk melihat pengaruh dari keseluruhan kebijakan pemerintah dan mekanisme pasar input-output, apakah memberikan insentif atau disinsentif terhadap usahatani kelapa di Kabupaten Flores Timur dianalisis dengan Koefisien Proteksi Efektif (Effective Protection Coefficient/ EPC), Transfer Bersih (Net Transfer/ NT), Koefisien Keuntungan (Profitability Coefficient/ PC), dan Rasio Subsidi Produsen (Subsidy Ratio to 
Producers/SRP). Informasi selengkapnya mengenai nilai EPC, NT, PC dan SRP dapat dilihat pada tabel 6 berikut ini

Tabel 6. Nilai Parameter Dampak Kebijakan pada Bidang InputOutput Komoditas Kelapa di Kabupaten Flores Timur, 2016

\begin{tabular}{lc}
\hline Parameter & Nilai \\
\hline $\begin{array}{l}\text { Effective Protection } \\
\text { Coefficient (EPC) }\end{array}$ & 1,24 \\
$\begin{array}{l}\text { Net Transfer (NT) } \\
\text { Profitability Coefficient }\end{array}$ & -7.513 .817 \\
$\begin{array}{l}\text { (PC) } \\
\text { Subsidy Ratio to Producers }\end{array}$ & $-0,72$ \\
(SRP) & \\
\hline
\end{tabular}

Sumber: Data primer diolah, 2016

Nilai Koefisien Proteksi Efektif (EPC) usahatani kelapa di Kabupaten Flores Timur adalah 1,24. Nilai EPC menunjukkan rasio lebih besar dari satu, dengan perkataan lain efektivitas kebijakan pemerintah saat ini adalah bersifat protektif atau melindungi dan mendorong produksi kelapa domestik untuk dikembangkan kearah perdagangan ekspor (minimal melalui perdagangan antar Daerah/Pulau). Kebijakan pemerintah yang diduga bersifat protektif terhadap komoditi ekspor ini adalah deregulasi tataniaga ekspor, subsidi input, subsidi ekspor, dan subsidi konsumen domestik.

Sementara transfer bersih (NT) yang menggambarkan tambahan surplus produsen atau berkurangnya surplus produsen yang diakibatkan oleh kebijakan pemerintah, dihitung dari hasil pengurangan antara keuntungan bersih yang diterima produsen dengan keuntungan bersih sosial (diasumsikan berlaku pada pasar bersaing sempurna), menunjukkan angka negatif yaitu sebesar
-7.513.817. Hal ini mengindikasikan telah terjadi pengalihan surplus dari produsen kelapa ke pihak lain. Artinya, dalam usahatani kelapa di Kabupaten Flores Timur telah terjadi pengalihan keuntungan dari pihak produsen (petani) ke pihak lain diluar usahatani kelapa, baik sebagai pelaku pasar input, maupun pelaku pasar output.

Ukuran relatif yang selanjutnya dapat digunakan untuk melihat perbandingan antara tingkat keuntungan bersih privat dengan keuntungan bersih sosial adalah dengan koefisien profitabilitas (PC) dan rasio subsidi produsen (SRP). Dalam hal ini angka PC menunjukkan pengaruh dari kebijakan pemerintah yang menyebabkan keuntungan privat berbeda dengan keuntungan sosial. Nilai PC lebih kecil dari satu menunjukkan tingkat keuntungan yang diterima petani lebih rendah daripada keuntungan-harga sosial yang seharusnya. Sedangkan SRP merupakan persentase subsidi atau insentif bersih atas penerimaan sosial. Nilai SRP negatif menunjukkan pengaruh dari adanya kebijakan pemerintah berdampak kepada produsen yang membayar biaya produksi lebih besar dari opportunity cost berproduksi, dan berlaku sebaliknya, bila nilai SRP positif.

Hasil analisis memperlihatkan bahwa angka PC adalah lebih kecil dari satu, yaitu 0,72. Ini berarti bahwa keuntungan yang diterima petani kelapa di Kabupaten Flores Timur lebih rendah daripada tingkat keuntungan-sosial yang seharusnya. Sementara itu, nilai SRP adalah negatif, yaitu $-0,17$. Artinya pengaruh dari kebijakan pemerintah dan mekanisme pasar seperti sekarang 
berdampak negatif terhadap struktur biaya produksi, sebab biaya yang diinvestasikan petani lebih besar daripada nilai tambah keuntungan yang dapat diterimanya.

Oleh sebab itu, dampak akhir dari kebijakan pemerintah dan mekanisme pasar yang berlaku saat ini secara ekonomik belum sepenuhnya mendukung terhadap pengembangan komoditas kelapa di Kabupaten Flores Timur, terutama dalam rangka pengembangan usaha pengolahan produk kelapa dan turunannya. Sebab daya saing produk kelapa pada saat ini terletak pada industri hilirnya, tidak lagi pada produk primer, dimana nilai tambah dalam negeri yang potensial pada produk hilir dapat berlipat ganda daripada produk primernya

\section{SIMPULAN}

Dampak dari instrumen kebijakan pemerintah dalam subsidi input saat ini memberikan perlindungan terhadap input domestik. Kondisi ini mengakibatkan petani di Kabupaten Flores Timur sebagai produsen kelapa tidak dapat memperoleh input domestik lebih murah daripada harga sosialnya (biaya domestik tinggi), sementara keuntungan diperoleh produsen input domestik. Sedangkan instrumen kebijakan pemerintah dalam harga dan mekanisme pasar output kelapa saat ini telah memberi dampak berupa perlindungan terhadap pembentukan harga kelapa, sehingga pendapatan yang diterima petani lebih tinggi daripada harga sosial yang seharusnya. Namun jika dilihat dari instrumen kebijakan pemerintah dan mekanisme pasar inputoutput yang berlaku saat ini memberikan dampak berupa kurangnya rangsangan (disinsentif) dari pemerintah terhadap petani produsen kelapa di Kabupaten Flores Timur, sehingga nilai tambah atau keuntungan yang diperoleh petani lebih rendah daripada keuntungan sosial yang seharusnya diterima petani.

\section{UCAPAN TERIMA KASIH}

Ucapan terima kasih terutama ditujukan kepada Kementerian Riset, Teknologi dan Pendidikan Tinggi sebagai pemberi dana penelitian Hibah Bersaing selama 2 tahun (2015-2016) dan pihakpihak yang telah membantu pelaksanaan penelitian ini.

\section{DAFTAR PUSTAKA}

Badan Pusat Statistik. (2016). Kabupaten Flores Timur dalam Angka. BPS Kabupaten Flores Timur.

Bank Indonesia. (2016). Nilai Tukar Tengah Rupiah. http://www.bi.go.id. [27 November 2016].

Kementerian Pertanian. (2010). Outlook Komoditas PertanianPerkebunan. Pusat Data dan Informasi Pertanian.

Monke, E.A. and S.R. Pearson. (1995). The Policy Analysis Matrix for Agricultural Development. Cornell University Press, Ithaca.

Pearson, S., Gotsch, C., dan Bahri, S. (2005). Aplikasi Policy Analysis Matrix pada Pertanian Indonesia. Terjemahan. Yayasan Obor Indonesia, Jakarta 